\title{
W(h)ither Warranty: The B(1)oom of Products Liability Theory in Cases of Deficient Software Design
}

\author{
Peter A. Alces $\dagger$
}

\section{TABLE OF CONTENTS}

Introduction

I. Warranty and Tort Recovery in the Commercial Law:

The Interdependence of Contract and Tort

A. Current Sales Warranty Law Under Article 2 of the

U.C.C.

B. Complementary Sources of Seller Liability for Deficient

Goods: "Fraud Unravels Everything"...

II. A Commercial World Without Implied Warranty

A. Courts Expanding Liability Beyond Warranty Using

Strict Products Liability Theory.

1. The Disclaimer Example..............................................286

2. The Privity Example......................................................28

3. Common Sense: How Courts Will Respond to the Weakness of Article 2B Warranty by Borrowing from Strict Products Liability.

B. The Unpeaceful Coexistence of Diametrically Opposed Errors: Excess in the Service of Politics.

1. Politics in the Drafting of U.C.C. Articles 2, 3, 4 , and 9

2. The Modern Revisions

C. The Deinands of Commerce and Technology: Of the Fortuity of Tangibility

D. Llex Llewellyn in Cyberspace

Copyright (C) 1999 California Law Review, Inc.

$\dagger$ Cabell Professor of Law, The College of William and Mary School of Law. I am indebted to my research assistants, Peter Ismay and Jennifer Vollmer, for their valuable contributions to this Article. I am also indebted to the students in my Spring 1998 Products Liability class for teaching me while they learned about product quality "in cyberspace." 
III. The Complementary Theory: Products Liability for Defective Software. .298

A. Defect: On the "Manufacture" and "Design" of Software.

B. The "Tangible" Property Requirement

301

C. "Property Other Than the Defective Product Itself" .302

D. The Curious Result That Would Remain .303

E. Conclusion .303

Conclusion .303 


\title{
W(h)ither Warranty: The B(l)oom of Products Liability Theory im Cases of Deficient Software Design
}

\author{
Peter A. Alces
}

Proposed Article $2 B$ of the Uniform Commercial Code is, like all commercial codification initiatives, a product of time and circumstance. The law would apply product quality jurisprudence to an evolving property form-the tangible/intangible hybrid that is the software license. In this Article, Professor Alces describes the Article $2 B$ drafters' approach to the implied warranty of merchantability, concluding that the draft's formulation is inconsiderate of commercial and jurisprudential realities. He surveys the contract and tort bases of warranties as they are formulated in Article 2 of the Uniform Commercial Code to support the conclusion that Article $2 B$ has failed to come to terms with the fit between commercial law's warranty regime and the complementary body of product quality law. Professor Alces then describes how courts determined to do justice might consult strict products liability law when Article $2 B$ 's implied warranty of merchantability fails to respond to the demands of technologically sophisticated commerce. The new Restatement (Third) of Torts: Products Liability may provide disappointed licensees the protections that an impotent merchantability warranty would deny them. This result could be avoided were Article $2 B$ 's implied warranty of merchantability drafted after the technology it would govern has been afforded the time to mature toward repose.

\section{INTRODUCTION}

I am a curmudgeon, and Frederick Beutel is one of my heroes. ${ }^{1}$ I do not think that we need a special article of the Uniform Commercial Code governing software licenses yet. ${ }^{2}$ As a general matter, the integrity of the U.C.C. must be maintained against the slings and arrows of outrageous codification. Because the technology that a uniform software

1. See Frederick K. Beutel, The Proposed Uniform [?] Commercial Code Should Not Be Adopted, 61 YALE LJ. 334 (1952).

2. See Marion W. Benfield, Jr. \& Peter A. Alces, Reinventing the Wheel, 35 WM. \& MARY L. REv. 1405 (1994). 
license law would govern has not reached anything even approaching repose, it is impossible to draft a U.C.C. software article in the best Llewellynesque tradition. But the particular focus of my scorn in this Article is the operation of a warranty of merchantability in nonconsumer transactions under Article $2 \mathrm{~B}$.

The drafters of Article 2B have maintained that the U.C.C. Article 2 formulation of the implied warranty of merchantability would be impotent in the non-mass-market software-license setting because the implied warranty of merchantability turns on the product's "ordinary purpose": " $[\mathrm{F}]$ or custom and other non-mass-market programs, a comparison to ordinary works of the same type is often meaningless and is at odds with the common law that applies in many development contracts." ${ }^{\prime 3}$ This statement reiterated the position the reporter had taken in the notes to the February 1998 Draft of Article 2B:

[T] he substantive question here deals with whether merchantability is a relevant standard and at all protective in cases where software is often relatively unique. For example, assume a commercial computer program that provides data compression functions on an $\mathrm{ABC}$ computer with an $\mathrm{XYZ}$ operating system. Merchantability would ask whether that product passes without objection among all data coinpression products of all types (e.g., mass market, Windows-based, Apple systems, etc.) even though the particular environment, approach and capabilities of this product may be unique. How that standard protects the licensee is not clear and in fact it may set out standards well below what the documentation provides. ${ }^{4}$

The reason given for eliminating the implied warranty of merchantability in non-mass-market licensing transactions-that it does not make sense to talk of the ordinary purpose of custoin-designed softwareconfuses ordinariness of purpose (e.g., data compression) with ordinariness of means (e.g., the particular software design that accomplishes the compression). It is as erroneous as suggesting that a newly designed automobile tire cannot be subject to the Article 2 implied warranty of merchantability because the innovative design does an ordinary thing in a new way. Such a narrow understanding of the implied warranty of

3. U.C.C. art. 2B discussion memo of Mar. 10, 1998, at 1 (Draft, Mar. 1998). [All versions of Article 2B are available on the Internet. See National Conference of Commissioners on Uniform State Laws, Drafts of Uniform and Model Acts of Official Site (last modified Sept. 2, 1998) $<$ http://www.law.upenn.edu/library/ulc/ulc.htm>. The Official Site offers the Article 2B drafts in several file formats, among which the pagination is inconsistent. In this Article and throughout this issue of the California Law Review, page references are to the pages as they are numbered in the Acrobat PDF file format. Only the prefaces to the drafts are cited by page number; all other material is cited by section number. The draft of August 1,1998 , has no page numbers in its on-line vcrsions, and therefore the preface of that draft is eitcd without page references. $E d$.]

4. U.C.C. $\$ 2 B-403$ general note 4 (Draft, Feb. 1998). 
merchantability in the custom-designed software context is uncommercial and inconsistent with the demands of product quality law.

A look at the development of Article 2B's warranty of merchantability helps to demonstrate this failing. The February 1998 Draft of Article 2B's implied warranty of merchantability provided:

(c) In cases not governed by subsection (a) [mass-market licenses] ... a licensor that is a merchant with respect to computer programs of that kind warrants to its licensee that:

(1) any physical inedium on which the program is delivered is merchantable; and

(2) the computer program will perform in substantial conformance with any promises or affirmations of fact contained in the documentation provided by the licensor at or before the delivery of the program.

(d) [However, a]n affirmation or prediction merely of the value of the information, a display or description of a portion of the information to illustrate the aesthetics or market appeal [of informational content], or a statement purporting to be merely the licensor's opinion or commendation of the information does not create a warranty ....

This-is not an implied warranty by any reasonable stretch of the imagination, and it may not even be a warranty at all. It essentially does no more than repeat, in diluted form, the substance of Article 2B's express warranty provision. ${ }^{6}$

5. U.C.C. \& 2B-403(c), (d) (Draft, Fcb. 1998). In that February Draft, the committee also considered an alternative formulation:

(a) A merchant licensor of a computer program warrants to the end user that the computer program is reasonably fit for the ordmary purpose for which it is distributed.

(b) A merchant licensor of a computer program warrants to a retailer that

(1) the program is adequately packaged and labeled as the agreement or circumstances may require; and

(2) in the case of inultiple copies, that the copies are, within the variations permitted by the agreement, of even kind, quality, and quantity, within each unit and among all the units involved.

(c) A warranty under this section does not pertain to the quality, aesthetics, market appeal, accuracy, or other characteristics of informational content whether or not the content is included within or created by a computer program or software.

Id. $\S 2 \mathrm{~B}-403$ rcporter's notes (emphasis added). Given this alternative's use of the "reasonably" modifier, it too departed substantially from the current Article 2 analogue. Hereinafter, all citations to Draft 2B are to the March 1998 version unless otherwise indicated.

6. See U.C.C. $\$ 2 \mathrm{~B}-402$ which provides:

(a) Subject to subsection (c), express warranties by the licensor are created as follows:

(1) Any affirmation of fact or promise made by the licensor to its licensee in any manner, including in a medium for commurication to the public such as advertising, which relates to the information and becomes part of the basis of the bargain creates an express warranty that the information required under the agreement shall conform to the affirmation or promise.

(2) Any description of the information which is inade part of the basis of the bargain creates an express warranty that the information shall conform to the description. 
It is worth noting who would and would not likely have been affected by the flaw present in the February Draft's implied warranty of merchantability. It would not have had an impact on ordinary consumers; consumer transactions were covered by the implied warranty of merchantability provided in subsection 2B-403(a), which governs "mass-market" transactions. ${ }^{7}$ And it is unlikely that large corporate licensees would have suffered under the February Draft of section 2B403 , as they generally have the bargaining power to insist on substantial express warranties, governed by section $2 \mathrm{~B}-402$, to protect their interests.

The most likely losers under the February Draft of section 2B-403, therefore, were small businesses that license, say, payroll or accounts receivable software not on the mass market. This is, to be sure, a niche market, but evidently a sufficiently significant niche to attract the attention of those who license software.

Licensors were the clear winners under the February Draft of section 2B-403; under its implied "warranty," their software did not need to be as good as the norm; it needed only to be the product of conscientious effort. The "requirement" that "the computer progranı will perform in substantial conformance with any promises or affirmations of fact contained in the documentation provided by the licensor," the so-called "warranty of documentation," opened the door for licensors to limit the scope and substance of their liability in documentation accompanying their software.

(3) Any sample, model, or demonstration of a final product which is made part of the basis of the bargain creates an express warranty that the performance of the information will reasonably conform to the performance illustrated by the model, sample, or demonstration, taking into account such differences between the sample, model, or demonstration and the information as it would be used as would appear to a reasonable person in the position of the licensee.

(b) It is not necessary to the creation of an express warranty that the licensor use formal words such as "warranty" or "guarantee," or state a specific intention to make a warranty. However, an affirmation or prediction merely of the value of the information, a display or description of a portion of the information to illustrate the aesthetics or market appeal of informational content, or a statement purporting to be merely the licensor's opinion or commendation of the information does not create a warranty.

(c) This section does not create an express warranty for published informational content. However, it does not preclude the creation of an express warranty under other law or the creation of an express contractual obligation for pubhished informational content. If an express warranty or contractual obligation is established for published informational content and is breached, the remedies of the aggrieved party arise under this article.

Id. (einphasis added).

7. See U.C.C. § 2B-403(a) (Draft, Feb. 1998) ("Unless excluded or inodified, a warranty that the computer program and physical medium shall be merchantable is implied in a nass-market transaction if the licensor is a merchant with respect to computer programs of that kind."). "Massmarket license" refers to a standard form that is prepared for and used in a consumer transaction in information directed at the general public. See id. $\S 2 \mathrm{~B}-102(30),(31)$.

8. Id. $\S 2 \mathrm{~B}-403(\mathrm{c})(2)$. 
In the February Draft, the reporter explained that section 2B-403's approach to the implied warranty of merchantability "is common in commercial licenses." Furthermore, rather than suggesting disingenuously that there is something fundainentally different about software, the reporter asserted that the U.C.C. itself has not kept pace with the development of commercial transactions. His candor is refreshing:

Most agreements disclaim merchantability; there are few reported commercial cases involving merchantability im any industry. Most licenses substitute a warranty of conformance to documentation. The section treats this as the presumed warranty, conforming to a commercial norm. This warranty measures performance by reference to what is said about the particular product. The argument in favor of retaining a merchantability warranty for transactions is that it would maintain a congruence between this Article and Article 2 and 2A. This may be ephemeral and could be reversed: those Articles should adapt to commercial practice. Merchantability measures performance obligations by reference to other like products, while the documentation warranty measures performance by what the licensor says about its product. ${ }^{10}$

The warranty of documentation thus appeared in the February Draft. By mcluding this provision, the Article 2B Drafting Committee had thrown down the gauntlet. Committees revising Articles 2 and 2A potentially would have to eliminate the warranty of merchantability, at least in transactions involving non-"mass-market" goods, if those Articles were to join the present state of the commercial world.

At its March 1998 meeting, ${ }^{11}$ however, the Article 2B Drafting Committee apparently rethought its position on the inefficacy of an implied warranty of inerchantability in the context of non-mass-market software and returned to the Article 2 fold:

(b) To be merchantable, a computer program and any physical medium on which it is delivered must:

(1)pass without objection in the trade under the contract description; [and] uted. ${ }^{12}$

(2) be fit for the ordinary purposes for which it is distrib-

So Article 2B would now embrace the standard that the reporter just one month earlier had essentially described as impotent in the software licensing context.

9. Id. § $2 \mathrm{~B}-403$ general note 4 (Draft, Feb. 1998).

10. Id. $\$ 2 \mathrm{~B}-403$ general note 5 .

11. The meeting was held in San Diego, California, March 27-29, 1998.

12. U.C.C. $\S 2 \mathrm{~B}-403$ (b). This version was passed by the Committee by a vote of 10-1. Telephone Interview with Stephen Y. Chow, Member of the Drafting Committee (Apr. 2, 1998). 
The thesis urged here is that if the warranty of merchantability in the software licensing context is in fact inefficacious, then the courts will likely look elsewhere to find a meaningful quality standard. That is, if courts conclude that the reporter was right when he observed that the $2 \mathrm{~B}$ merchantability warranty is meaningless without a mature transactional context within which to formulate conceptions of ordinary fitness, judges and juries will find other legal theories to protect disappointed software licensees.

This Article endeavors to put Article 2B's implied warranty of merchantability in context. Part I describes the state of warranty liability under current Article 2 of the U.C.C. to provide the foundation for an analysis of Article 2B's implied warranty of merchantability. Part II then considers how Article 2's warranty fits with the patchwork of tortbased product liability theories developed by the courts. Part III explains how the products liability law could fill the void left by the absence of meaningful implied warranty of merchantability protection in Article 2B. It concludes that the application of strict products liability theories to deficient software is inevitable, and will only be more robust im the absence of meaningful warranty protection.

WARRANTY AND TORT RECOVERY IN THE COMMERCIAL LAW: THE INTERDEPENDENCE OF CONTRACT AND TORT

\section{A. Current Sales Warranty Law Under Article 2 of the U.C.C.}

There are three warranty of quality provisions in current Article 2 of the U.C.C.: the section 2-313 express warranty, ${ }^{13}$ the section 2-314 implied warranty of merchantability, ${ }^{14}$ and the section $2-315$ implied

13. U.C.C. \$ 2-313 (1995). The section provides:

Express Warranties by Affirmation, Promise, Description, Sample.

(1) Express warranties by the seller are created as follows:

(a) Any affirmation of fact or promise made by the seller to the buyer which relates to the goods and becomes part of the basis of the bargain creates an express warranty that the goods shall conform to the affirmation or promise.

(b) Any description of the goods which is made part of the basis of the bargain creates an express warranty that the goods shall conform to the description.

(c) Any sample or model which is made part of the basis of the bargain creates an express warranty that the whole of the goods shall conform to the sample or model.

(2) It is not necessary to the creation of an express warranty that the seller use formal words such as "warrant" or "guarantee" or that he have a specific intention to make a warranty, but an affirmation merely of the value of the goods or a statement purporting to Id. be merely the seller's opinion or commendation of the goods does not create a warranty.

14. Id. \& 2-314. The section provides:

Implied Warranty: Merchantability; Usage of Trade.

(1) Unless excluded or modified (Section 2-316), a warranty that the goods shall be merchantable is implied in a contract for their sale if the seller is a merchant with respect to 
warranty of fitness for particular purpose. ${ }^{15}$ These formulations, alternative and overlapping, ${ }^{16}$ are products of their time. ${ }^{17}$ But because each is cast in sufficiently flexible language to fit evolving transactional patterns, they have held up quite well since their drafting in the $1950 \mathrm{~s}$.

In part, this is a credit to the drafters. But the warranties' durability also suggests the centrality of warranty in commercial transactions. Warranties are fundamental to transactors' expectations, and they allocate risk in a manner that is consistent with transactional exigencies. Basically, warranties fix risk.

This Part reviews the Article 2 warranties and compares them with analogous legal doctrines concerning implied quality representations. It examines the interaction of the Article 2 warranties with each other and with alternative implied quality assurance doctrines in order to provide perspective for appraisal of the Article $2 \mathrm{~B}$ implied warranty of merchantability.

goods of that kind. Under this section the serving for value of food or drink to be consumed either on the premises or elsewhere is a sale.

(2) Goods to be merchantable must be at least such as

(a) pass without objection in the trade under the contract description; and

(b) in the case of fungible goods, are of fair average quality within the description; and

(c) are fit for the ordinary purposes for which such goods are used; and

(d) run, within the variations permitted by the agreement, of even kind, quality and quantity within each unit and among all units involved; and and

(e) are adequately contained, packaged, and labeled as the agreement may require;

(f) conform to the promises or affirmations of fact made on the container or label if any.

(3) Unless excluded or modified (Section 2-316) other implied warranties may arise from Id. course of dealing or usage of trade.

15. Id. $\S 2-315$. The section provides:

Implied Warranty: Fitness for Particular Purpose.

Where the seller at the time of contracting has reason to know any particular purpose for which the goods are required and that the buyer is relying on the seller's skill or judgment to select or furnish suitable goods, there is unless excluded or modified under the next section Id. an implied warranty that the goods shall be fit for such purpose.

16. For demonstrations of how more than one of these provisions may apply to the same transaction, depending on the facts and circumstances surrounding the deal, see, e.g., Klein v. Sears, Roebuck \& Co., 773 F.2d 1421 (4th Cir. 1985); Custom Automated Mach. v. Penda Corp., 537 F. Supp. 77 (N.D. Ill. 1982); Berkeley Pump Co. v. Reed-Joseph Land Co., 653 S.W.2d 128 (Ark. 1983); Mennonite Deaconess Home \& Hosp., Inc. v. Gates Eng'g Co., 363 N.W.2d 155 (Neb. 1985); Warren v. Joseph Harris Co., 313 S.E.2d 901 (N.C. Ct. App. 1984); Gall v. Allegheny County Health Dep't, 555 A.2d 786 (Pa. 1989); see also William D. HAwKLAND, UNIFORM COMMERCIAL CODE SERIES, $§ 2-315: 01$, at 546-47 (1992) (noting overlap between sections 2-314 and 2-315 and the fact that a seller's statements may create warranties under both sections 2-313 and 2-315).

17. See William Twining, KaRL Llewelly and the Realist Movement 311 (1973) ("[Llewellyn] fornulated [the Code] with reference to a particular problem which arose in a specific context at a particular moment in history."). 
As creatures of contract, warranties constitute representations: representations about the present, and representations about the future.

The Article 2 express-warranty provision, section $2-313$, provides that a seller who makes a representation about the quality of the goods sold will be held to that representation. The resulting warranty pertains both to affirmations concerning the present state of the goods (e.g., "This watch is made of gold"), 18 and to promises regarding the goods' performance in the future (e.g., "This watch will keep accurate time"). ${ }^{19}$ Section 2-313 also makes clear that the express-warranty representation may arise from samples, models, and description of goods. ${ }^{20}$ Finally, the terms of the bargain fix the scope of the express warranty: a representation is actionable as an express warranty only if it becomes "part of the basis of the bargain"21 between buyer and seller. Courts, however, have not made it very difficult for buyers to satisfy the "basis of the bargain" requirement. ${ }^{22}$

The Article 2 implied warranty of merchantability, section 2-314, imposes liability on a seller for sales of non-"merchantable" goods. In effect, every sale of goods by a merchant ${ }^{23}$ seller entails an implied representation that the goods are "fit for the[ir] ordinary purpose[]."24

18. See, e.g., Palmer v. A.H. Robins Co., 684 P.2d 187, 208 (Colo. 1984); Cricket Alley Corp. v. Data Terminal Sys., Inc., 732 P.2d 719, 722 (Kan. 1987); Yost v. Millhouse, 373 N.W.2d 826, 829 (Minn. Ct. App. 1985); Bernstein v. Sherman, 497 N.Y.S.2d 298, 300 (Just. Ct. 1986).

19. See, e.g., Custom Automated Mach., 537 F. Supp. at 82-83; Krieger v. Nick Alexander Imports, Inc., 285 Cal. Rptr. 717, 724-25 (Ct. App. 1991); Jones v. Abriani, 350 N.E.2d 635, 644-45 (Ind. Ct. App. 1976); Boese-Hilburn Co. v. Dean Mach. Co., 616 S.W.2d 520, 529 (Mo. Ct. App. 1981).

20. See U.C.C. $\$ 2-313(1)(b)$, (c) (1995).

21. Id. $\S 2-313(1)$. The term "bargain" is used as well in the Article 1 general definition of "agreement." Id. § 1-201(3).

22. See, e.g., Massey-Ferguson, Inc. v. Laird, 432 So. $2 d 1259$ (Ala. 1983); Winston Indus., Inc. v. Stuyvesant Ins. Co., 317 So. 2d 493, 497 (Ala. Civ. App. 1975) ("the determining factor in this case under the newly enacted [U.C.C.] is not reliance by the purchaser on the seller's warranty, but whether it is part of the "basis of the bargain"'); Hauter v. Zogarts, 534 P.2d 377, 384 (Cal. 1975) ("the affirmation, once inade, is a part of the agreeinent, and lack of reliance by the buyer is not a fact which would take the affirmation out of the agreement") (internal citation omitted); Carpetland U.S.A. v. Payne, 536 N.E.2d 306, 308 (Ind. Ct. App. 1989) (holding buyer does not need to show reliance on seller's statement to prove assertion was part of the basis of the bargain). John Murray argues, not entirely convincingly, that the basis of the bargaim requirement is distinguishable from a reliance test. See John E. Murray, Jr., "Basis of the Bargain": Transcending Classical Concepts, 66 MiNN. L. REV. 283, 317-25 (1982).

23. A "merchant" is a person who

deals in goods of the kind or otherwise by his occupation holds himself out as having knowledge or skill peculiar to the practices or goods involved in the transaction or to whom such knowledge or skill may be attributed by his employinent of an agent or broker or other intermediary who by his occupation holds himself out as having such knowledge or skill.

U.C.C. $\S 2-104(1)$ (1995).

24. Id. $\S 2-314(2)(c)$. Section 2-314(2) also contains alternative formulations of the merchantability standard requiring, for example, that fungible goods be of "fair average quality 
Courts have construed this standard to recognize the buyer's understanding of "merchantability."25

The Article 2 implied warranty of fitness for particular purpose, section 2-315, is a hybrid of the express warranty and implied warranty of nerchantability provisions. To be liable under the warranty of fitness, the seller must be aware that the buyer is relying on his expertise in selecting goods that are suitable for the buyer's particular purpose. The representation that the goods are "fit" may be inferred from the circunistances surrounding the sale. ${ }^{26}$

The three Article 2 warranties overlap ${ }^{27}$ to assure comprehensive coverage. But they are not monolithic; insofar as the warranties are creatures of contract, parties to sales transactions remain free to contract out of warranty protection, no matter how comprehensive the scope of the express and implied warranty provisions. ${ }^{28}$

Since the warranties are not identical, the means to disclaim each one effectively may not be the same in all instances. Consequently, courts may need to consider one type of warranty liability but not the other two because a disclaimer successfully insulates the seller from liability under only two of the three warranty provisions. In fact, cases considering the scope and interrelation of the three warranty sources often involve disclaimer. ${ }^{29}$ I discuss the importance of disclaimer below. ${ }^{30}$

within the[ir] description" and that goods be "adequately contained, packaged, and labeled" according to any agreed-upon terms. Id. $\$ 2-314(2)(\mathrm{b})$, (e).

25. Price inay be used as an indicator of the quality intended. See id. $\$ 2-314 \mathrm{cmt} .7$ ("The price at which a merchant closes a contract is an excellent index of the nature and scope of his obligation."); see also Dale v. King Lincoln-Mercury, Inc., 676 P.2d 744, 748 (Kan. 1984) (implied warranty of merchantability varies with age, mileage, and purchase price of car); Faulkingham v. Seacoast Subaru, Inc., 577 A.2d 772, 774 (Me. 1990) (holding quality of used car determined by age, mileage, and purchase price); Sylvia Coal Co. v. Mercury Coal \& Coke Co., 156 S.E.2d 1, 7 (W. Va. 1967) (allowing jury to consider price when determining existence of implied warranty in connection with quality).

26. See, e.g., Whitehouse v. Lange, 910 P.2d 801, 805-07 (Idaho Ct. App. 1996); Rubin v. Marshall Field \& Co., 597 N.E.2d 688, $691-92$ (Ill. App. Ct. 1992); Roupp v. Acor, 384 A.2d 968, 970 (Pa. Super. Ct. 1978).

27. Arguably, the three warranties spring from the same fundamental source. In Randall $v$. Newson, the court captured the sum and substance of warranty law when it observed that "the fundamental undertaking [of the seller] is, that the article offered or delivered shall answer the description of it contained in the contract." 2 Q.B.D. 102, 109 (C.A. 1877).

28. See U.C.C. \$2-316 (1995).

29. See, e.g., Auto-Teria, Inc. v. Ahern, 352 N.E.2d 774 (Ind. Ct. App. 1976); Collins Radio Co. v. Bell, 623 P.2d 1039 (Okla. Ct. App. 1980).

30. See discussion infra Part II.A.1. 


\section{B. Complementary Sources of Seller Liability for Deficient Goods: "Fraud Unravels Everything"31}

The U.C.C.'s remedial provisions do not exist in a vacuum. The buyer of deficient goods, even goods obtained through transactions within the scope of Article 2, is not limited to the Code when seeking to recover against the seller. He may look as well to complementary legal principles or bodies of law to fill gaps left open by the Code. This Section considers those coinplementary sources.

Section 1-103 of the U.C.C. ${ }^{32}$ recognizes that even a coinprehensive and preemptive codification ${ }^{33}$ cannot respond to all needs of comnercial transactors, and that there is room for operation of supplementary common law and statutory rules that cooperate with the U.C.C. to assure the parties the benefit of their bargam. Parties may, therefore, have recourse to a complementary principle if a court finds that it has not been "displaced" by Article 2. It is in such crevices of the statutory regime that common law fraud principles have taken root.

For instance, when a seller niakes an inaccurate representation during sales-contract negotiations, that representation may later support a tort-based misrepresentation action by the buyer. If the seller's misrepresentation is intentional, the seller will be liable for fraud and, if the .jurisdiction allows, vulnerable to exenuplary damages. ${ }^{34}$

But a misrepresentation need not be intentional for the buyer to recover. Section $402 B$ of the Restatement (Second) of Torts recognizes the viability of innocent misrepresentation actions against sellers. ${ }^{35}$

31. John M. Finnis, Natural LAW ANd Natural Rights 288 (1980).

32.

Supplementary General Principles of Law Applicable. Unless displaced by the particular provisions of this Act, the principles of law and equity, including the law inerchant and the law relative to capacity to contract, principal and agent, estoppel, fraud, misrepresentation, duress, coercion, mistake, bankruptcy, or other validating or invalidating cause shall supplement its provisions.

U.C.C. $\S 1-103$ (1995).

33. See William D. Hawkland, Uniform Commercial "Code" Methodology, 1962 U. ILL. LF. 291, 309-13 (1962), for comprehensive treatment of what it means for the U.C.C. to be construed as a "code."

34. See Restatement (SECOND) of Torts § 522A (1964); see also BMW of N. Am., Inc. v. Gore, 517 U.S. 559, 577-78 (1996) (ruling that failure to disclose a pre-sale repair to plaintiff's car constituted fraud and raised possibility of punitive damages); Briggs Transp. Co. v. Starr Sales Co., 262 N.W.2d 805, 811 (lowa 1978) (holding that trial court was justified in rendering judgment for punitive damages for the fraudulent breach of a contract for the sale of electronics equipment); Saberton v. Greenwald, 66 N.E.2d 224, 227 (Ohio 1946) (allowing punitive damages for fraudulent sale of reconditioned watch as a new watch).

35. See Restatement (SECOND) OF ToRTs $\S 402 B$ (1964). Section 402B provides:

Misrepresentation by Seller of Chattels to Consumer.

One engaged in the business of selling chattels who, by advertising, labels, or otherwise, makes to the public a misrepresentation of a material fact conceming the character or quality of a chattel sold by him is subject to liability for physical harm to a consumer of the chattel caused by justifiable reliance upon the misrepresentation, even though 
Similarly, section 9 of the recently promulgated Restatement (Third) of Torts: Products Liability ${ }^{36}$ recognizes the "Liability of Commercial Product Seller or Distributor for Harm Caused by Misrepresentation." Section 9 provides: "One engaged in the business of selling or otherwise distributiug products, who in connection with the sale of a product, makes a fraudulent, negligent, or innocent misrepresentation concerning the product, is subject to liability for harm to persons or property caused by the misrepresentation." ${ }^{37}$

In fact, section 9 may impose liability in more cases than would original section 402B, which required that the representation be made "by advertising, labels, or otherwise ... to the public." 38 The reporters of the products liability Restatement acknowledge that the extent of a seller's liability for innocent misrepresentations to individuals other than through advertising to "the public at large" is an open question, even under the section 9 formulation. Consequently, the developer of custom-designed computer software would seein to have inore reason to be concerned by section 9 than by section 402B, the terms of which contemplate inore distinctly public representations than does section 9 .

Importantly, the products liability Restatement reporter's note that section 9 liability represents an alternative theory to a seller's liability under U.C.C. section 2-313. ${ }^{39}$ Consequently, a court could find that the seller did not inake a warranty, express or otherwise, but still did make the type of representation that would support an action under section 9.

Clements Auto Co. v. Service Bureau Corp..$^{40}$ illustrates the inter action of the U.C.C. warranties and the common law doctrine of
(a) it is not made fraudulently or negligently, and
(b) the consuiner has not bought the chattel from or entered into any contractual relation with the seller.

Id.; see also Seely v. White Motor Co., 403 P.2d 145, 151-52 (Cal. 1965) (en banc) (stating that under $402 \mathrm{~B}$, liability can be imposed without a finding of neghigence where the manufacturer of a product has made representations that the product is free from defects in material and workmanship, even though there is no privity of contract); Klages v. General Ordinance Equip. Corp., 367 A.2d 304, 311 ( $\mathrm{Pa}$. Super. Ct. 1976) (allowing a fmding of liability for failure of a mace pen to "effect[] an instantaneous, immediate, and complete incapacitation of an assailant" as represented); Godwin Aircraft, Inc. v. Houston, 851 S.W.2d 816, 822 (Tenn. Ct. App. 1992) (finding liability for negligent imisrepresentation regarding airplane's condition at the time of sale); Crocker v. Winthrop Labs., 514 S.W.2d 429, 433 (Tex. 1974) (holding that where drug was represented to be free from all dangers of addiction and treating physician relied on the representation, the drug company was liable when representations proved false and decedent's death resulted).

36. I discuss the Products Liability Restatement in more detail, infra Part III.

37. Restatement (Third) of Torts: Products Liability $\$ 9$ (Proposed Final Draft, Apr. $1,1997)$.

38. Restatement (SECOND) OF TORTS $§ 402 B$ (1964).

39. Restatement (Third) of Torts: Products Liability $\$ 9 \mathrm{cmt}$. e (1997) ("The rule stated in this Section provides a remedy in tort in many cases in which a remedy for breach of express warranty is also available to the plaintiff.").

40. 444 F.2d 169 (8th Cir. 1971). 
misrepresentation in the context of computer software. Service Bureau Corporation (SBC) provided inadequate data processing services to the plaintiff. ${ }^{41}$ SBC relied on the lack of express warranties and the disclaimer of all implied warranties in its contracts with plaintiff to successfully resist breach of warranty liability. ${ }^{42}$ But plaintiff had also proceeded on an innocent misrepresentation theory, alleging that SBC had represented "that the proposed data processing system would, when fully implemented, be capable of providing [plaintiff] sufficient information in a form such that when properly utilized, it would constitute an effective and efficient tool to be used in inventory control."43 The lower court found that SBC's representation was innocent, but that it still constituted actionable fraud.

On appeal, defendant argued that warranty law preempted the innocent misrepresentation theory, because " $[u]$ nder the relevant law, innocent misrepresentation and warranties, either express or implied, are substantially similar in nature." 44 The U.C.C. was not the applicable law at the time of the transaction, but the defendant relied on the legislature's subsequent passage of the U.C.C. to argue that the legislature intended for statutory warranty law to preempt the operation of common law innocent misrepresentation theories in sales transactions. ${ }^{45}$

The Eighth Circuit found that scienter, or intent to defraud, was not required to sustain a fraud action in the state. ${ }^{46}$ Moreover, the court

41. SBC was to provide inventory reports containing a detailed history for each item, a movement history during specified months, on-hand figures, and a computation of the number of weeks' supply of each item delivered on hand. These reports were to be delivered in January of 1966, but due to a programming error by SBC, they were not received until July of 1966 . Further, the imput inethod SBC employed was slow and expensive, and the reports were error-ridden. See id. at 173-75.

42. See id. at 176 .

43. Id. at 175. The lower court found that SBC had made other specific actionable misrepresentations to plaintiff, specifically that

1. automating the firm's accounting was the only way the plaintiff could have an inventory control system;

2. adequate controls were installed in the system to prevent errors and keep them to a minimum;

3. Friden Flexowriters were suitable devices to input data into the system, that eight Flexowriters were sufficient, that clerical personnel could operate the Flexowriters, and that the Flexowriters would create a hard copy of the invoice for the customer's order;

4. weekly sales management reports would allow management by exception.

See id.

44. Id. at 180. The Uniform Sales Act had been the basis of the existing commercial law in Minnesota simce 1917. See 1917 Minn. Laws 465.

45. See Clements Auto Co., 444 F.2d at 179-80.

46. See id. at 176. The elements of a misrepresentation action in Minnesota are as follows:

1. There inust be a representation; 2 . That representation must be false; 3 . 1t must have to do with a past or present fact; 4 . That fact must be material; 5 . It must be susceptible of knowledge; 6 . The representor must know it to be false, or in the alternative, must assert it as of his own knowledge without knowing whether it is true or false; 7 . The rcpresentor must intend to have the other person induced to act, or justified in acting upon it; 8 . That 
dismissed the defendant's preemption argunent by relying on a prior state court holding that "a general disclaimer clause is ineffective to negate reliance on even innocent misrepresentations.... There is no indication that the disclaimer of warranty negates reliance on false representations made with or without intent to deceive."47 Finally, the court noted that the passage of the U.C.C. did not affect its conclusion. ${ }^{48}$ This holding is $\mathrm{m}$ perfect keeping with the language of U.C.C. section 1-103 which accommodates, rather than frustrates, the operation of an innocent misrepresentation theory.

The Clements analysis would seem pertinent, and perhaps even more appropriate, in states where warranty law provides buyers, lessees, or licensees less protection than does misrepresentation law, particularly innocent misrepresentation law. And if that is the case, could an Article 2B that essentially abrogates implied warranty liability in favor of express warranty truly accomplish uniformity?

In a thoughtful article, JoEllen Mitchell-Lockyer treats the uneasy fit between the Code and supplementary misrepresentation theories. ${ }^{49}$ She argues,

Modern torts for unintentional seller misrepresentation are displaced by Article II on sales in a number of different ways. First, such alternate tort liability can conflict with particular Article II provisions, most notably the parol evidence rule, the disclaimer and limitations sections, the seller's right to cure, and the substantive and procedural requirements for rejection and revocation of acceptance. Moreover, the Article II sales provisions include novel approaches to warranty, breach, damages, and cancellation, among others, that would be frustrated by these tort actions. Though, for example, the sales provisions are 'silent' on the contract affirmative defenses, use of innocent

person must be so imduced to act or so justified in acting; 9 . That person's action must be in reliance upon the representation; 10 . That person must suffer damage; 11 . That damage must be attributable to the misrepresentation, that is, the statement must be the proximate cause of the imjury.

Id. at 175 (citing Hanson v. Ford Motor Co., 278 F.2d 586, 591 (8th Cir. 1960)). The court also emphasized the Minnesota Supreme Court's statement in Swanson v. Domning, 86 N.W.2d 716, 72021 (Minn. 1957), to the effect that

[a]n intent to deceive no longer is necessary. Nor is it necessary to prove that defendants knew the representations were false. It is not necessary that the statement be recklessly or carelessly made. It makes no difference how it is made if it is made as an affirmation of which defendant has knowledge and it is in fact untrue. The right of recovery in a case of this kind is based on the fact that such statement, being untrue in fact, relied upon by the other party in entering into the transaction, has resulted in the loss to him which he should not be required to bear.

Clements Auto Co., 444 F.2d at 176 (imternal citation and quotation omitted).

47. Id. at 178-79 (citations omitted).

48. See id. at 180 .

49. JoEllen Mitchell-Lockyer, Common Law Misrepresentation in Sales Cases-An Argument for Code Dominance, 19 Forum 361 (1984). 
misrepresentation as a ground for such a defense can hamper the operation of numerous Article II provisions relating to the scope of the bargain. Finally, though Article II does not contain a body of specialized provisions relating solely to fraud and misrepresentation, section 2-721 preempts conflicting common law requiring election of remedies for fraud and misrepresentation in goods transactions. ${ }^{50}$

I do not take issue with Mitchell-Lockyer's conclusion that the aggressive use of complementary misrepresentation theories undermines the balance struck by the uniform commercial law. In fact, I am sure that she is right. But her arguments for Code dominance are premised on the Code's preemption of a body of law. Once the commercial law becomes a means of insulating licensors from liability for the deficiencies in their products at the expense of licensees, courts may find the preemption argunient less tenable. In that context it will be easier for disappointed contracting parties to argue that the Code does not adequately provide the fundamental safeguards that are the basis of warranty law. ${ }^{51}$ And Article 2B appears to establish just such a context.

II

\section{A COMmercial WorLd Without IMPLIED WARRANTY}

A further review of the current Article 2 law provides a frame of reference to guide critique of Article $2 B$ 's implied warranty of merchantability in non-mass-market licenses. It also helps illuminate how the law might respond to a commercial world without real impliedwarranty protections.

\section{A. Courts Expanding Liability Beyond Warranty Using Strict Products Liability Theory}

The warranty provisions of Article 2 of the U.C.C. were drafted at a dramatic time in the evolution of our commercial economy-a time when the fit between warranty and complementary theories supporting recovery for goods that failed was edgy at best. ${ }^{52}$ Unsurprisingly, those

50. Id. at 375-76 (footnotes omitted).

51. See Peter A. Alces \& David Frisch, Commercial Codification as Negotiation, 32 U.C. DAvis L REv. (forthcoming Jan. 1999) (manuscript at 45-48, on file with author) (discussing Randall v. Newson, 2 Q.B.D. 102 (C.A. 1877)).

52. See Grant Gilmore, On the Difficulties of Codifying Commercial Law, 57 YALE L.J. 1341 (1948). Gilmore writes,

In the present post-war period, following ten years of unprecedented expansion of the national productive capacity, industrial and commercial practices are fluid and subject to sudden change. 
interested in striking a balance between the rights of buyers and sellers looked elsewhere when conceptions of consent did not sufficiently explain transactions. This especially happens when a party's "consent" to a contract is more fiction than reality. Consequently, even contract remedies manifest elements of tort.

To be sure, the prominence of tort varies among the three warranties. Express warranties are founded in contract. But even here, to the extent that buyer expectations may determine the "basis of the bargain," 53 the operation of objective tort principles is visible.

The implied warranty of fitness for particular purpose, too, seems primarily a creature of contract, at least insofar as it contemplates something akin to a meeting of the minds, that is, the seller's reason to know that the buyer is relying on the seller's expertise. But a more objective, tort-like judgment surfaces in the particular purpose warranty as well through the determination of whether goods are, in fact, "fit" for a particular purpose.

The implied warranty of inerchantability, however, is most clearly the product of tort. Sellers breach the warranty if their goods are not "fit for the[ir] ordinary purpose[]," 54 or will not "pass without objection in the trade." 55 The cases confirm that those determinations proceed from an objective, reasonableness perspective. ${ }^{56}$ So understood, the

\footnotetext{
It is easy to predict that as air freight gropes its way out of its experimental stage, new legal patterns for controlling and financing goods in transit will develop; it is less easy to say what the new patterns will be.

$\cdots$

Industrial finance, particularly in the acquisition of short term working capital, has greatly changed during the past ten years; it is difficult to say whether the change was a temporary war-production phenomenon or the beginning of a permanent shift in our financing habits.

...

It is entirely possible that our distribution system is also undergoing significant cbange. Cooperative associations of producers, retailers, and to a lesser extent of consumers, are increasingly cutting the middleman's profit from the cost of marketing. National and regional mail order houses and cham stores have the same effect. The integrated operation, with centralized control which may extend from the extraction of raw materials to the retail distribution of finished products, may become typical of the next stage of industrial organization.... [T]ncrease in the range and complexity of goods and services put on the market will undoubtedly lead to far-reaching changes in our thinking about sellers' obligations....
}

Id. at 1356-58; see also Twining, supra note 17, at 305 ("[T] Code was drafted in the expectation that it would probably have to last without major alterations for a substantial period... with the prospect of an increasing momentum in the rate of technical and other change.").

53. U.C.C. $\$ 2-313(1)$ (1995). The use of an objective standard is suggested by the question proposed in comment 8: "What statements of the seller have in the circumstances and in objective judgment become part of the basis of the bargain?" Id. $\$ 2-313 \mathrm{cmt}$. 8. Murray proposes that the courts use a reasonable expectations test for determining the basis of the bargain. See Murray, supra note 22 , at $317-18$.

54. U.C.C. \$ 2-314(2)(c) (1995).

55. Id. § 2-314(2)(a).

56. See, e.g., Greene v. Boddie-Noell Enters., Inc., 966 F. Supp. 416, 419 (W.D. Va. 1997) (noting that "it is the lawyer's cballenging job to define the term 'mercbantability' in [the] case in 
implied warranty of merchantability affords courts the means to police the bargain by reference to the transactional context, including the relative sophistication and bargaining power of the parties. And once courts find a license in the implied warranty law, they are, arguably, less likely to look for it elsewhere in terms that would frustrate the consistent application of commercial contracting principles. That is, once the implied warranty of merchantability is appreciated as responding to the interests vindicated by tort law, ostensibly coinplementary but essentially contradictory recovery theories will not frustrate transactor expectations.

Nevertheless, a contract element still exists in the implied warranty of merchantability: the warranty's substance in the particular case is to be determined by reference to the deal between the buyer and seller, the goods described, and the set price. ${ }^{57}$ As such, like the other two warranties, it remains subject to the incidents of contract, including, importantly, disclaimer. This vulnerability to the incidents of contract is why warranties, express or implied, have heretofore been considered insufficient means to redress the compromised interest that may result when a buyer's quality expectations are frustrated.

\section{The Disclaimer Example}

All three of the U.C.C. Article 2 warranty provisions are subject to section 2-316's disclaimer provision. ${ }^{58}$ While the express warranty can

some objective way so that the court or jury can make a determination whether that standard has been breached") (emphasis added) (quoting JAMES J. WhiTE \& RoberT S. SUMmers, HaNDBook OF THE LAW UNDER THE UNIFORM COMMERCIAL CODE $\$ 9.7$, at 356 (2d ed. 1980)).

57. See U.C.C. $\& 2-314 \mathrm{cmt}$. 1 (1995) ("The question when the warranty is imposed turns basically on the meaning of the terms of the agreement as recognized in the trade."); $i d . \$ 2-314 \mathrm{cmt}$. 7 ("In cases of doubts as to what quality is intended, the price at which a merchant closes a contract is an excellent mdex of the nature and scope of his obligation under the present section.").

58. See id. § 2-316. Section 2-316 provides:

Exclusion or Modification of Warranties.

(1) Words or conduct relevant to the creation of an express warranty and words or conduct tending to negate or limit warranty shall be construed wherever reasonable as consistent with each other; but subject to the provisions of this Article on parol or extrinsic evidence (Section 2-202) negation or limitation is moperative to the extent that such construction is unreasonable.

(2) Subject to subsection (3), to exclude or modify the implied warranty of merchantability or any part of it the language must mention merchantability and in case of a writing must be conspicuous, and to exclude or modify any implied warranty of fitness the exclusion must be by a writing and conspicuous. Language to exclude all implied warranties of fitness is sufficient if it states, for example, that "There are no warranties which extend beyond the description on the face hereof."

(3) Notwithstanding subsection (2)

(a) unless the circumstances indicate otherwise, all implied warranties are excluded by expressions like "as is", "with all faults" or other language which in common understanding calls the buyer's attention to the exclusion of warranties and makes plain that there is no implied warranty; and

(b) when the buyer before entering into the contract has examined the goods or the sample or model as fully as he desired or has refused to examine the goods there is no 
not so much be "disclaimed" as refuted, 59 the seller may avoid the implied warranties of merchantability and fitness for particular purpose by mvoking the right verbal formula. ${ }^{60}$

The availability of disclaimer in transactions between parties of unequal bargaining power helped motivate development of strict products liability law. Recall that in Henningsen $v$. Bloomfield Motors, ${ }^{61}$ the New Jersey Supreme Court considered an automobile sales contract disclaiming all express and implied warranties other than the manufacturer's limited ninety-day or 4,000 mile warranty..$^{62}$ The warranty was a standard form prepared by the Automobile Manufacturers Association-a form, the court concluded, that "has metamorphosed

implied warranty with regard to defects which an examination ought in the circumstances to have revealed to him; and

(c) an implied warranty can also be excluded or modified by course of dealing or course of performance or usage of trade.

(4) Reinedies for breacli of warranty can be limited in accordance with the provisions of this Article on liquidation or limitation of damages and on contractual modification of Id. remedy (Sections 2-718 and 2-719).

59. A seller may be able to invoke the parol evidence rule, codified at U.C.C. section 2-202, to argue that an oral representation did not become part of his final agreement with a buyer. When a final agreenent is in writing, lowever, two restrictions limit a seller's protection through a written disclaimer and section 2-202: (1) the written agreement must be "intended by the parties as a final expression of their agreement," id.; and (2) the parties inust have intended that the writing contain the "complete and exclusive" terms of their agreement, id. § 2-202(b). See 1 JAMEs J. WHITE \& ROBERT S. Summers, UNiform Commercial Code $\S 11-2$, at 586 (4th ed. 1995); see also Investors Premium Corp. v. Burroughs Corp., 389 F. Supp. 39 (D.S.C. 1974); Green Chevrolet Co. v. Kemp, 406 S.W.2d 142 (Ark. 1966).

60. See U.C.C. § 2-316(2), (3)(a); see also id. § 2-316 cmt. 7 ("Paragrapll (a) of subsection (3) deals with general terms such as 'as is,' 'as they stand,' 'with all faults,' and the like. Such terms in ordinary commercial usage are understood to mean that the buyer takes the entire risk as to the quality of the goods involved.").

61. 161 A.2d 69 (N.J. 1960).

62. See id. at 74 . The reverse side of the contract contained $81 / 2$ inches of fine print, titled "Conditions." The seventh paragraph, two-thirds of the way down the page, described the warranty:

7. It is expressly agreed that there are no warranties, express or implied, made by either the dealer or the manufacturer on the motor vehicle, chassis, of [sic] parts furnished hereunder except as follows.

The manufacturer warrants each new motor vehicle (including original equipment placed thereon by the manufacturer except tires), chassis or parts manufactured by it to be free from defects im material or workmanship under normal use and service. Its obligation under this warranty being limited to making good at its factory any part or parts thereof which shall, within ninety (90) days after delivery of such vehicle to the original purchaser or before such vehicle has been driven 4,000 miles, whichever event shall first occur, be returned to it with transportation charges prepaid and which its examination shall disclose to its satisfaction to have been thus defeetive; this warranty being expressly in lieu of all other warranties expressed or implied, and all other obligations or liabilities on its part, and it neither assuunes nor authorizes any other person to assume for it any other liability in connection with the sale of its vehicles.

Id. at 74 (quoting sales contract) (emphasis in originai). 
the warranty into a device to limit the maker's liability." 63 The court did not mince words:

[W] arranties originated in the law to safeguard the buyer and not to limit the liability of the seller or manufacturer. It seems obvious in this instance that the motive was to avoid the warranty obligations which are normally incidental to such sales. The Ianguage gave little and withdrew much. In return for the delusive remedy of replacement of defective parts at the factory, the buyer is said to have accepted the exclusion of the maker's liability for personal injuries arising from the breach of the warranty, and to have agreed to the elimination of any other express or implied warranty. An imstinctively felt sense of justice cries out against such a sharp bargain. ${ }^{64}$

The court thus invalidated the disclaimer of the implied warranty of merchantability as "inimical to the public good." 65

Clearly, Henningsen was a seminal strict products liability case. It effectively limited the operation of contract principles in what the court determined to be a not-entirely-consensual transaction. ${ }^{66}$ To be fair, Henningsen was a pre-U.C.C. case arising under the Uniform Sales Act. But while the U.C.C. Article 2 warranties respond in part to the warranty and disclaimer deficiencies at issue in Henningsen, the case nonetheless remains significant to warranty law both for its views of the "bargain," and for its demonstration that the contract limitations of warranty were an important factor in the development of the strict products liability law.

\section{The Privity Example}

Henningsen also examined contract law privity doctrine. Chrysler, the manufacturer-defendant, argued that because its contractual connection was with Bloomfield Motors, and not with Henningsen, there was no basis upon which to impose warranty liability on Chrysler. The court showed little patience for this defense:

63. Id. at 78 .

64. Id. at 85 .

65. Id. at 95.

66. Other courts have struck down warranty disclaimers on similar public policy grounds. See, e.g., Woodruff v. Clark County Farm Bureau Coop. Ass'n, 286 N.E.2d 188, 196 (Ind. App. Ct. 1972) (holding warranty disclaimers disfavored and strictly construed against sellers for public policy reasons); Loomis v. Stu Maguire's Equip. Sales, Inc., 511 N.Y.S.2d 439, 441 (Sup. Ct. App. Div. 1987) (holding warranty disclaimer provision in contract for sale of used truck void as against public policy); Bernstein v. Sherman, 497 N.Y.S.2d 298, 301 (Just. Ct. 1986) (concluding warranty disclaimer as to condition of auto frame would be invalid as against public policy); Durham v. CibaGeigy Corp., 315 N.W.2d 696, 701 (S.D. 1982) (holding herbicide manufacturer's warranty disclaimer invalid as unconscionable and contrary to public purpose); Stauffer Chem. Co. v. Curry, 778 P.2d 1083, 1091 (Wyo. 1989) (holding warranty disclaimers are not favored and are strictly interpreted for public policy reasons). 
The limitations of privity in contracts for the sale of goods developed their place in the law when marketing conditions were simple, when maker and buyer frequently met face to face on an equal bargaining plane and when many of the products were relatively uncomplicated and conducive to imspection by a buyer competent to evaluate their quality. ${ }^{67}$

Though Henningsen construed pre-U.C.C. warranty law, Article 2 does not offer a comprehensive response to the privity issues that warranty cases raise. First, there is little indication that Article 2 as enacted says anything about vertical privity. ${ }^{68}$ Second, section $2-318$ 's three alternatives $^{69}$ determine the cases in which there is sufficient privity, but may not provide exhaustive treatment of even the horizontal warranty issue. $^{70}$

In Salvador v. Atlantic Steel Boiler Co., ${ }^{71}$ the Supreme Court of Pennsylvania addressed a horizontal privity question within the scope of section 2-318. The court began by noting its earlier abrogation of the vertical privity requirement. ${ }^{72}$ Hence, although Pennsylvania had

67. Henningsen, 161 A.2d at 80 .

68. See Alces \& Frisch, supra note 51, at 55-60. But see White \& Summers, supra note 59, § 11-2, at 586 (stating that Alternatives B and C of section 2-318 and "various nonstandard versions of 2-318" affect both horizontal and vertical privity).

69. See U.C.C. \$ 2-318 (amended 1966), which provides:

Third Party Beneficiaries of Warranties Express or Implied.

Alternative A

A seller's warranty whether express or implied extends to any natural person who is in the family or household of his buyer or who is a guest in his home if it is reasonable to expect that such person may use, consume or be affected by the goods and who is injured in person by breach of the warranty. A seller may not exclude or limit the operation of this section.

Alternative B

A seller's warranty whether express or implied extends to any natural person who may reasonably be expected to use, consume or be affected by the goods and who is injured in person by breacl of the warranty. A seller may not exclude or limit the operation of this section.

Alternative C

A seller's warranty whether express or implied extends to any person who may reasonably be expected to use, consume or be affected by the goods and who is injured by breach of the warranty. A seller may not exclude or limit the operation of this section with respect to imjury to the person of an individual to whom the warranty extends.

70. See id. \$ $2-318 \mathrm{cmt} 3$ (stating that Alternative $A$ "is not intended to enlarge or restrict the developing case law," that Alternative B "is designed for states where the case law has already developed further and for those that desire to expand the class of beneficiaries," and that Alternative C follows "the trend of modern decisions").

71. 319 A.2d 903 (Pa. 1974).

72. See id. at 904 (citing Kassab v. Central Soya, 246 A.2d 848 (Pa. 1968)). "Privity of contract is that connection or relationship which exists between two or more contracting parties." BLACK's LAW DICTIONARY 1079 (5th ed. 1979); see also 4 ARTHUR L. CORBIN, CONTRACTS $\$ 778$ (1951); 8 Samuel Williston, ConTracts $\$ 998 \mathrm{~A}$ ( $3 \mathrm{~d}$ ed. 1964). If a purchaser is injured by a defective product he inay, of course, bring a breach of warranty claim against the seller. As contracting parties they are in privity. If the injured purchaser wishes to sue the manufacturer or wholesaler lie must satisfy or overcome the vertical privity requirement. Because lis contractual relationship is only with the retail seller, lie cannot establislı vertical privity with the wlrolesaler; lie is one step further 
adopted the most restrictive 2-318 form, Alternative $A,{ }^{73}$ the court found that the state's adoption of the strict products liability theory embodied in section 402A of the Restatement (Second) of Torts ${ }^{74}$ essentially neutralized the Article 2 privity requirements:

[A] manufacturer by virtue of Section $402 \mathrm{~A}$ is effectively the guarantor of his products' safety.... Our courts have determined that a manufacturer by marketing and advertising his product impliedly represents that it is safe for its intended use. We have decided that no current societal interest is served by permitting the manufacturer to place a defective article in the stream of commerce and then to avoid responsibility for damages caused by the defect. ${ }^{75}$

The Pennsylvania Supreine Court thus recognized the fundamental affinity between the interests vindicated by the complementary warranty and strict products liability theories and disregarded privity requirements of warranty in order to achieve symmetry between buyer and seller in the law governing the quality of products.

\section{Common Sense: How Courts Will Respond to the Weakness of Article 2B Warranty by Borrowing from Strict Products Liability}

Just as law and equity have merged ${ }^{76}$ the parallel development of Article 2 of the U.C.C. and strict products liability theory has effected a merger of tort and contract principles in the defective products law. Though the limitations of warranty theory were at first among the

removed from the manufacturer. The question of vertical privity is: who can be sued? The question of horizontal privity is: who can sue? The purchaser can sue the retail seller because they are in privity. When the vertical privity requirement is abolished, a plaintiff inay also sue any other entity in the distributive chain. But if the purchaser's wife is injured by a defeetive product, may she maintain a breach of warranty action? See U.C.C. § 2-318. May the purchaser's injured employee sue suceessfully? If a bystander is injured is he too entitled to recover for breach of warranty? These are questions of horizontal privity. See id. $\S 2-318 \mathrm{cmt}$. 1 .

73. See supra note 69.

74. See RESTATEMENT (SECOND) OF TORTS $\$ 402 A$ (1965). Section 402 A provides:

The Special Liability of Seller of Produet for Physical Harm to User or Consumer.

(1) One who sells any product in a defeetive condition unreasonably dangerous to the user or consumer or to his property is subject to liability for physical harm thereby caused to the ultimate user or consumer, or to his property, if

(a) the seller is engaged in the business of selling such a product, and

(b) it is expected to and does reach the user or consumer without substantial change in the condition in which it is sold.

(2) The rule stated in Subseetion (1) applies although

(a) the seller has exercised all possible care in the preparation and sale of his product, and

(b) the user or consumer has not bought the product from or entered into any Id. contractual relation with the seller.

75. Salvador, 319 A.2d at 907 .

76. See FED. R. CIV. P. 2 ("There shall be one form of action to be known as 'eivil action'."). 
reasons for development of strict liability theory, cases like Salvador reveal that the expansion of strict products liability has now, in a curious symbiosis, itself redefined the contours of warranty.

The imteraction between warranty and strict products liability suggests that the two theories can no longer develop wholly independently. As demonstrated by cases such as Salvador and Kassab, expansion of one may encourage expansion of the other; warranty liability expands once strict products liability breaks through barriers such as the privity requirements at issue in those two cases. Most importantly for our purposes, however, we must remain aware that it was warranty law's limitations that engendered development of strict products liability. Once we appreciate how strict products liability law complements warranty law, we may expect that legislation limiting warranty liability in settings where warranty is important will only encourage the application of strict products liability to fill those gaps once more. Conversely, if we want to avoid this phenomenon, we must look to a strengthened warranty law to provide a solid jurisprudential basis for preventing the strict products liability response.

To discern the extent of the jurisprudential tension between warranty and strict products liability, it is worthwhile to consider the sources of some fundanental commercial law conceptions.

\section{B. The Unpeaceful Coexistence of Diametrically Opposed Errors: Excess in the Service of Politics}

\section{Politics in the Drafting of U.C.C. Articles 2, 3, 4, and 9}

Times were easier for the drafters of uniform commercial law when they promulgated current Article 2. The sales law at the time applied contract primciples to recurring transactions among relatively sophisticated transactors. From the drafting perspective, Article 2 was bilateral legislation, in that it did not favor one party's interests over the other. Large institutional sellers such as the Ford Motor Company or Sears were as often buyers as they were sellers, and these large institutional interests would not have been served by legislation that favored either buyers or sellers as a class. ${ }^{77}$ The drafters, therefore, had a real interest in enacting legislation that would provide certain, predictable results, rather than legislation that would accommodate one busmess interest at the expense of another. ${ }^{78}$

77. In general, Article 2 does not offer significant consumer protections. Rather, specific consumer protection laws supplement the Code and common law. See MichaEl M. Greenfield, Consumer law: A Guide for Those Who Represent Sellers, Lenders, and Consumers 1-6 (1995) (tracing the development of consumer protection legislation in the twentieth century).

78. See U.C.C. \& 1-102; TwINING, supra note 17, at 290-91, 303-04. 
The importance of these institutional entities' positions should not be underestimated. Witness Articles 3 and 4 of the U.C.C., which many have noted were essentially controlled by dominant financial interests in both their original and revised iterations. ${ }^{79}$ U.C.C. Article $2 \mathrm{~A}$ also displays the influence of institutional politics, and provides yet another perspective for assessinent of Article 2B. Article 2A, governing leases of personal property, was based on the Article 2 model, as though the relationship between lessors and lessees was as essentially congruent as that between repeat buyers and sellers. Of course, Hertz the lessor is rarely Hertz the lessee. So it may not be immediately clear why the drafters of Article 2A seemed to have followed the Article 2 rather than the Article 9 model. In operation, however, Article $2 \mathrm{~A}$ is a hybrid, drawing upon sales principles when appropriate (e.g., warranties) ${ }^{80}$ and drawing on secured transactions principles when appropriate (e.g. lessor's right to recover lease property upon lessee's default). ${ }^{81}$

\section{The Modern Revisions}

The most recent U.C.C. revision initiatives have readjusted the neat unilateral/bilateral dichotoiny posited above. Additional interest groups have inade more of a contribution to the structure of the current formulations than was manifest in the original versions of Article 2, Article 2A, and Article 9. Advocates of enhanced consumer protection have participated actively in the Article 2 and Article 9 revision efforts, introducing to those commercial contexts consumer protections imported

79. During the original drafting process of Article 4, Professor Beutel, not a supporter of the U.C.C. project, argued, "In fact, this Article [Article 4] is so one-sidedly drawn in favor of the banking interests that any banker who insisted on exercising the rights given him by this 'Code' would probably be under suspicion by the better business bureau." Beutel, supra note 1, at 362. Professor Gilmore, a drafter of Article 9 and a general supporter of Article 4, also could not disagrce completely with Beutel's assessment. An "efficient collection system is in the private interest of banks as much as it is in the public interest of customers of banks ... . Section 4-103 goes far beyond what is wise or permissible in allowing banks to rewrite the law their way whenever things get tough ...." Grant Gilmore, The Uniform Commercial Code: A Reply to Professor Beutel, 61 YALE L.J. 364, 37677 (1952). Despite the rise of the American consumer movement in the years subsequent to the adoption of Article 4, the revision of Articles 3 and 4 changed little from the consumer's standpoint. See Edward Rubin, Efficiency, Equity and the Proposed Revision of Articles 3 and 4, 42 ALA. L. Rev. 551, 586-92 (1991) (describing how pressure from financial institutions during the drafting process skewed the balance among the rights of parties to negotiable instruments transactions within the scope of revised Articles 3 and 4 of the Uniform Commercial Code).

80. See, e.g., U.C.C. $\$ \S 2 A-210$ (express warranties), 2A-212 (implied warranty of merchantability), 2A-213 (implied warranty of fitness for particular purpose) (1995). The official comments note that these code seetions were revised to reflect that cases extended Article 2 warranties to lease transactions. See id. $\S 2 \mathrm{~A}-212 \mathrm{cmt}$. (citing Glenn Dick Equip. Co. v. Galey Constr., Inc., 541 P.2d 1184, 1193 (Idaho 1975)); id. § 2A-213 cmt. (citing All-States Leasing Co. v. Bass, 538 P.2d 1177, 1183 (Idaho 1975)).

81. See id. $\S \S 2 A-525,9-503$ (1995). "Subsection [2A-525] (2), a revised version of the provisions of Section 9-503, allows the lessor, on a Section $2 A-523(1)$ or $2 A-523(3)$ (a) default by the lessee, the right to take possession of or reclaim the goods." Id. $\S 2 \mathrm{~A}-525 \mathrm{cmt} .2$. 
from common law tort principles and from state and federal regulatory regimes. The involvement of these groups reflects a maturation in the structure of commerce to a point where non-institutional buyers now have discrete interests that challenge the bilateral model. The result, particularly in the case of the draft revision of Article 2, is a contracts statute which, in many cases, does not rely upon conceptions of consent so much as it does on the law of less than consensual relations. ${ }^{82}$ Draft Revised Article 9, too, includes extensive provision of individual consumer rights and would effect a sea change in secured-transactions law, as least msofar as it relates to consumer financing.

At this point, the revision of Article $2 \mathrm{~A}$ is on hold pending developments in the revision of Article 2 and the promulgation of an Article 2B. It may be difficult, however, for the drafters of an Article 2A Revision to discern sufficient commonality between Revised Article 2 and Proposed Article 2B to know which course to follow. Draft Revised Article 2 and Proposed Article 2B proceed from diametrically opposed frames of reference. Draft Revised Article 2 vimdicates consumer (buyer) imterests at the expense of large institutional sellers (as well as small, not-so-imstitutional sellers). Article $2 \mathrm{~B}$, on the other hand, would make the world safe(r) for computer software developers and licensors (the parties analogous to Article 2 sellers).

This incoherence between the two nascent bodies of commercial law is perhaps nowhere more manifest, and regrettable, than in the warranty provisions formulated in the two drafts. Draft Revised Article 2 affords buyers enhanced warranty protection in relation to current Article 2. The drafters of Proposed Article 2B, on the other hand, believe that software licensing law essentially cannot provide implied warranty of merchantability protection in the case of non-mass-market software. Unless some sound reason can be discerned for this difference-some reason independent of the market or political power of the concerned constituencies-then the fundamental coherence that has been the object of Article 2 and Article 2-like law will be fatally compromised. And, of course, software licensees will suffer. In the next Section, I examine the Article 2B drafters' conclusion that software is sufficiently "different" as to render the implied warranty of merchantability impotent $\dot{m}$ software licensing transactions.

\section{The Demands of Commerce and Technology: Of the Fortuity of Tangibility}

Unsurprisingly, Article 2B drafters have depended on the unusual qualities of software to justify special warranty treatment for

82. See, e.g., proposed section $2-404$, which extends express warranties to remote purchasers and transferees. U.C.C. $\S 2-404$ (Discussion Draft, Mar. 1998). 
non-mass-market licenses. Software is, after all, distinctive, if not unique. If this form of property did not have characteristics that set it apart from Inore familiar forms of property, it would not need to be governed by newly developed law in the first place. Those engaged in software transactions certainly can establish that the property imterests they deal with are less familiar than are the traditional property interests dealt with in more familiar commercial law contexts.

Nonetheless, this approach also sets up something of a selffulfilling prophecy. To be sure, intellectual property, and particularly software, is neither completely goods nor completely services. Software is a hybrid, owing incidents to both the tangible and less tangible. This tension in the nature of software allows the Article 2B reporter to draw on analogies from both the tangible goods law and intangible services law to support formulations in the licensing law. ${ }^{83}$ And the fact that the "thing of value," the program, may be transferred either by physical or electronic media does lend sonie support to a warranty scherne that is not solely dependent on either the purely tangible or the purely intangible property interest warranties. ${ }^{84}$ This train of thought has a crude logic, and it can be cast in terms that pay due deference to the rhetoric of U.C.C. jurisprudence. After all, the Code should conform to business practices, taking into account the course of their evolution and ultimately fixing rules that strike the right commercial balance..$^{85}$

Ultimately, however, there is only false logic in understanding Article $2 \mathrm{~B}$ warranty provisions along lines that track and give substantive legal effect to formal differences such as tangibility. The tangible/ intangible distinction is a convenient one, but it lacks the substance that the drafters of Article $2 \mathrm{~B}$ would claim for it.

Warranty should be determined by the demands of commerce, not the fortuity of tangibility. No one has niade the case that commerce requires the distinction drawn by Article 2B; no one has demonstrated that the justifications for warranty are not present in recurring non-1nassmarket software transactions. Indeed, not just efficient commerce, but the health of the software industry, may deniand even more warranty protection for licensees in the software setting, and, hence, an overall more licensee-friendly understanding of non-niass-1narket software's "ordinary purpose."

83. See id. \& 2B-403 general notes 1-3. "Article $2 \mathrm{~B}$ warranties blend three different legal traditions." Id. $\$ 2 \mathrm{~B}-403$ general note 1 . One tradition focuses on the result, that the product conforms to ordinary standards of performance. The second tradition concerns the process, the contract performance, and the third tradition stems from "contracts for informational content." Id.

84. For the argument that the Article 2 warranty of merchantability does not fit non-massmarket software transactions, see U.C.C. $\$ 2$ B-403 general note 4 (Draft, Feb. 1998).

85. See Gilmore, supra note 79 , at 365 ("The task of . . the Code is to state basic principles under which busmess transactions can be carried out."). 
Cem Kaner and David Pels have concluded that imposing limitations on the warranties of quality attending software licenses undermines the software development mdustry. ${ }^{86}$ Their critique responds both to an overly restricted appreciation of the ordinariness of custom-designed software and to arguments that because the market for software is less mature than some other areas, the nascent software imdustry should enjoy more latitude to create and distribute deficient products.

Kaner and Pels point out that software developers in fact already do sell software that they know is imperfect. ${ }^{87}$ But that does not mean that such software would be "unmerchantable" under a merchantability test such as that found in current Article 2. "Merchantable" does not mean "perfect." Indeed, the elegance of the current Article 2 merchantability definition is that it is flexible; different quality standards operate in different contexts. The determinative factor in deciding when something is fit for its ordmary purpose is whether it will pass without objection in the trade..$^{88}$ And this mquiry is not changed by the fact that there may typically be more "bugs" in custom-designed software. 89

After acknowledging that software cannot be perfect-as no good subject to Article 2 is expected to be-the authors, nonetheless, conclude that substantial merchantability protection may be indispensable for the software industry:

Article 2B makes it too easy for companies to ship products with significant, known defects. It provides no meamingful recourse to the customers of these products. We think that this is grievous error. What value is the preservation of "freedom of contract" (for the drafter of an adhesion contract) if the net effect will be long-term damage to a leading imdustry? How many times do we have to lose, or see crippled, key American industries before we learn that there is great social value in the protection of customer satisfaction with American manufacturers? ${ }^{90}$

That sentiment, that nothing less than the fortunes of a great American industry may be inplicated in decisions regarding the substance of software warranties, is not mere hyperbole. At the time of Henningsen $v$.

86. See Cem Kaner \& David L. Pels, Article 2B and Software Customer Dissatisfaction (May 27, 1997) (last modified Dec. 23, 1997) <http://www.badsoftware.com/stats.htm>. Kaner has worked with software for 21 years. He is the senior author of the best-selling book, TESTING COMPUTER SOFTWARE ( $2 \mathrm{~d}$ ed. 1993), and a frequent speaker on software quality and customer satisfaction. He is also an attorney, and has attended the Article 2B drafting committee meetings since February 1996. Pels has nranaged technical support for software or coniputer-related hardware for 21 years. The authors have been researching and writing a book on software custoner satisfaction since 1994.

87. See id. at I 4 ("The vast majority of problems that customers called about were known problems, problems that we knew about when we shipped the product.").

88. See, e.g., Coffer v. Standard Brands, Inc., 226 S.E.2d 534 (N.C. Ct. App. 1976).

89. See Kaner \& Pels, supra note 86 , at I 11.

90. Id. at 931 . 
Bloomfield Motors, ${ }^{91}$ the American automobile industry so dominated that its trade group, the Automobile Manufacturers Association (the AMA), was able to impose contractual provisions on consumers that essentially abrogated a seller's warranty liability. ${ }^{92}$

The applicable sales law at that time was the Uniform Sales Act, which gave effect to the AMA's strong pro-seller language. ${ }^{93}$ As noted above, the court in Henningsen responded to the AMA form contract and the limitations of pre-Code warranty theory by focusing on public policy to afford buyers the protection that the contract law had denied them. The decades that followed Henningsen saw the decline of that American industry, and, at least in part, this was due to the relative decline in quality of domestically-manufactured automobiles. ${ }^{94}$ Could that or something like that happen in response to Article 2B's warranty of merchantability for non-mass-inarket software? Karl Llewellyn's perspective may be pertinent.

\section{Llex Llewellyn in Cyberspace}

The jurisprudential view of Karl Llewellyn imported techniques for resolving "trouble cases" from the practices of the Cheyenne" and applied them to the most sophisticated transactions of the mid- to latetwentieth century. Courts have continued to apply U.C.C. sales principles to increasingly sophisticated transactions and transactors, including transfers of technology captured in computer software. ${ }^{96}$

Llewellyn's prescience is manifest not just in the durability of his statutory formulations, but also, importantly, in his appreciation of the limits of commercial codification. He recognized that commercial legislation is not so much imposed on transactors as it is a product of

91. 161 A.2d 69 (N.J. 1960).

92. See text accompanying supra notes 61-63.

93. Compare Uniform Sales Act § 15 ("Implied Warranties of Quality"), and § 71 ("Variation of Implied Obligations"), with U.C.C. § 2-316 ("Exclusion or Modification of Warranties"), and § 2719 ("Contractual Modification or Limitation of Remedy").

94. This is part of the argument made by Kaner \& Pels, supra note 86.

95. Llewellyn discusses "trouble cases" im KarL N. Llewellyn \& E. Adamson Hoebel, The Cheyenne Way: Conflict and Case law in Primitive Jurisprudence 27-29 (1941). Llewellyn suggests that courts might analyze such trouble cases in commercial situations using what he called, "situation sense." See Karl N. Llewellyn, Remarks on the Theory of Appellate Decision and the Rules or Canons About How Statutes Are to Be Construed, 3 VAND. L. REv. 395, 397 (1950). See generally TwINING, supra note 17, at 216-27 (discussing Llewellyn's general concept of "situation sense"). The term "sense of the situation" appears in the comments to section 2-612 of the Uniform Commercial Code. U.C.C. $\$ 2-612 \mathrm{cmt} .3$ (1995).

96. See, e.g., Advent Sys. Ltd. v. Unisys Corp., 925 F.2d 670 (3d Cir. 1991); RRX Indus., Inc. v. Lab-Con, Inc., 772 F.2d. 543 (9th Cir. 1985); NMP Corp. v. Parametric Tech. Corp., 958 F. Supp. 1536 (N.D. Okla. 1997); Neilson Bus. Equip. Ctr., Inc. v. 1talo V. Monteleone, 524 A.2d 1172 (Del. 1987); Richard Haney Ford, Inc. v. Ford Dealer Conuputer Servs., 461 S.E.2d 282 (Ga. Ct. App. 1995); Communications Groups, Inc. v. Wamer Communications, Inc., 527 N.Y.S.2d 341 (Civ. Ct. 1988). 
transactional context. That is, he understood commercial legislation to be a function of the commercial context that it would regulate; it must respond to existing probleins. If a statute affords courts the opportunity to apply law that justly balances the rights of contracting parties, those courts are more likely to respect that statute. Otherwise, the statute will be impotent and ultimately ignored, ${ }^{97}$ and, as Llewellyn realized, courts will look to "covert tools" to strike that fair balance. ${ }^{98}$ In other words, if warranty fails in Article $2 \mathrm{~B}$, then courts may be disposed to consult other means to fix the rights of the parties, means that might ultinately be inimical to the commercial law.

Just as enhanced warranty protections for buyers have provided the means to inaintaim U.C.C. Article 2's integrity in the face of decisions like Henningsen, ${ }^{99}$ the warranty provisions of Article 2B, if properly formulated, could assure that courts would not look for ways to avoid limitations on the software licensees' ability to recover when software fails.

The "right" formulation of an inplied warranty of inerchantability in the software licensing context must emerge from the commercial context; it cannot be imposed by those who would create the law in a manner inconsiderate of transactional dynaimics. The drafters of $2 \mathrm{~B}$ have acknowledged that, as of yet, they are unable to come to terms with the concept of "ordinary purpose" when software fails. The commercial sales and personal property leasing laws have not stumbled on that concept. The Article 2B drafters' failure to appreciate what a software warranty of merchantability should look like is not entirely their faultthe time is simply not ripe; the technology the warranty would govern has not achieved repose. A handful of cases cannot support quality determinations regarding a technology that will change dramatically several times over between the time the sponsoring organizations bless Article 2B and the last state to adopt it has done so. Grant Gilmore, an advocate of the original U.C.C., saw the repose problem confronting

97. See Gilmore, supra note 52, at 1355 (referring to the Code's "greatest single virtue: a keen awareness of the importance of reflecting actual business practice"); see also TwiNiNG, supra note 17, at 313-21 (describing the original Code drafters' approach to codifying commercial practice).

98. Llewellyn expressed concern that, in the absence of section 2-302, courts would turn to these "covert tools" in order to avoid unconscionable results contract terms coinpelled. See John E. Murray, Jr., The Chaos of the "Battle of the Forms": Solutions, 39 VAND. L. REv. 1307, 1321 (1986) ('Under the classical theory ... the courts used 'covert tools' to prevent unconscionable results. Llewellyn was concerned that the existing judicial process lacked certainty, stability, and predictability. He believed that section 2-302 brought this process 'out into the open'...."). According to Llewellyn, "Covert tools are never reliable tools." Karl N. Llewellyn, Book Reviews, 52 Harv. L. Rev. 700, 703 (1939) (reviewing O. Prausnitz, The Standardization of Commercial Contracts in English and Continental Law (1937)).

99. See, e.g., Wright v. Dow Chem., 845 F. Supp. 503, 511 (M.D. Tenn. 1993); Ford Motor Co. v. Tritt, 430 S.W.2d 778, 781-82 (Ark. 1968); Knipp v. Weinbaum, 351 So. 2d 1081, 1084-85 (Fla. Dist. Ct. App. 1977); Larsen v. Pacesetter Sys., Inc., 837 P.2d 1273, 1289 (Haw. 1992). 
transactions that had been settled in the law. His observations in that context resonate here:

[T] he times may well be out of joint for the production of a Commercial Code.

We have noted... how technological change cracked and twisted the traditional structure of sales law and how ... a sudden and unexpected mutation in what had been thought to be a stable legal form left a codifying statute obsolete before enactment.

In the present post-war period, following ten ycars of unprecedented expansion of the national productive capacity, industrial and commercial practices are fluid and subject to sudden change. It is not hard to demonstrate that change is taking place and that the rate of change is accelerating, but when, at what point and in what form the economy will achieve relative stability, if there is indeed such a prospect at all, is unpredictable. It is, however, possible to lay hold of a few straws in the wind. ${ }^{100}$

Gilmore was a curmudgeon too.

\section{III \\ The Complementary Theory: \\ Products LIABILITY FOR DEFECTIVE SofTwARE}

As noted above, when warranty failed transactors in the Article 2 context, strict products liability filled the breach. As our national economy evolved to the point at which recurring transactions were less often accomplished at arms' length, the need for a mechanism to protect those who would be mjured by products became manifest. Strict products liability was mevitable; it was the necessary result of the evolution in the law that attended the increasing impersonalization of contractual relationships. ${ }^{101}$ Strict products liability was not the only reaction to that change in the ways of contracting, ${ }^{102}$ but it has become perhaps the primary means by which the tortification of contracts has been

100. Gilmore, supra note 52, at 1356-57.

101. Llewellyn frequently referred to a horse transaction as representing the informal, personal transaction as opposed to the contemporary commercial transactions not conducted within "arms' length." See Twining, supra note 17, at $220 \mathrm{n} .71$; see also Karl N. Llewellyn, Across Sales on Horseback, 52 HARv. L. REv. 725, 737 (1939); Karl N. Llewellyn, The First Struggle to Unhorse Sales, 52 HARV. L. REV. 873 (1939).

102. See Restatement (ThiRd) of Torts: Products Liability, Foreword by Geoffrey C. Hazard, Jr. (Tentative Draft No. 1, 1994).

[T] he basic task of legal formulations is to seek an appropriate balance, so far as it can be realized in tort law, between providing reasonable protection for consumcr and worker interests and stating reasonably viable standards of conduct for producers of goods .... [D]efinitions [of product defect] reflect the origins of modern products liability in the Id. law or warranty and negligence. 
accomplished. I now examine the authorities that might apply were this phenomenon to repeat itself in the Article 2B context.

In May of 1997, the American Law Institute promulgated the Restatement (Third) of Torts: Products Liability. This initiative is the first comprehensive restatement treatment of the principles that might determine liability between transactors were courts to find that contract failed to achieve justice between the parties. While the focus of the Restatement, and of this liability theory generally, is on personal injury, the terms of the Restatement and the principles that undergird it may resonate as well in the software licensing context defined by Article 2B.

This Part considers the consequences of the new Restatement if Article $2 \mathrm{~B}$ is read as effectively abrogating the implied warranty of merchantability. In brief, where warranty fails, frustrated transactors and courts may resort to strict liability theories that heretofore have been unnecessary (and perhaps even inconsistent with the warranty theories available by analog ${ }^{103} \mathrm{im}$ the pre-Article $2 \mathrm{~B}$ software licensing world).

\section{A. Defect: On the "Manufacture" and "Design" of Software}

Software that fails may be deemed defective pursuant to the terms of the Restatement under two circumstances. First, a product that "departs from its intended design even though all possible care was exercised in the preparation and marketing of the product"104 may be deeined to suffer from a manufacturing defect. In other words, there would be a manufacturing defect in the software if it departed from its intended design.

A strict products liability action on account of a manufacturing defect is available in instances where the merchantability warranty would not arise. That is, even if a particular product is deemed not to have failed its ordinary purpose, because, for instance, the court determines that the product does not have a discernible "ordinary purpose," 105 the court could nonetheless determine that the product departed from the product's design specifications. ${ }^{106}$

Second, a product may be deemed to suffer a Restatement Section 2(b) design defect: " $[\mathrm{A}]$ product is defective in design when the foreseeable risks of harm posed by the product could have been reduced or avoided by the adoption of a reasonable alternative design by the

103. For a discussion of the intellectual property cases that have relied on the Article 2 warranties by analogy, see Peter A. Alces \& Harold F. See, The Commercial Law of INTELlectual Property \$§ 13.1-13.5 (1994).

104. Restatement (Third) of Torts: Products Liability \& 2(a) (1997) (defining a "manufacturing defect").

105. U.C.C. $\$ 2 B-403$ general note 4 (Draft, Feb. 1998).

106. See RESTATEMENT (THIRD) OF TORTS $\$ 2 \mathrm{cmt}$ c c (1997) (manufacturing defects). 
seller... and the omission of the alternative design renders the product not reasonably safe." 107

An example may help to illustrate the two types of defects. Suppose that a software developer undertakes to deliver software that will cure the "millennium-bug" problem in a licensee's computer systems. If the software fails to perform as the parties intended, unfortunate consequences may well follow: the licensee's accounts-receivable records may be lost, payroll hopelessly confounded, and security compromised.

The licensee might plausibly attempt to premise a strict products liability action on either a manufacturing or design-defect theory. The fit between the two defect theories in the context of software deficiency is admittedly uneasy because the facts do not necessarily fit the alternative defect bases embodied in the Restatement. But while the designdefect standard seems at first glance to better suit deficient software development, a case can be made that the manufacturing-defect test is the more appropriate standard.

Consider first the more obvious alternative: software deficiency as design defect. If the millennium-bug software fails, the disappointed licensee inay complain that the failure could have been avoided by a "reasonable alternative design." That formulation in fact may in some cases impose on the licensor a duty greater than that captured in the 2B-403 inplied warranty of merchantability. If the licensor is liable for not utilizing a reasonable alternative design, licensors will need to be certain that they have considered all alternative designs that licensee's experts may establish at trial would have been reasonable. If the licensor is held only to a fit-for-ordinary-purpose standard, the licensor could establish in response to the warranty action that the software was fit for the ordinary purpose even if it was not fit for the extraordinary purposes of the licensee. But the licensor may well be able to argue successfully that a reasonable alternative design would not have avoided the problems caused by the deficient software. ${ }^{108}$

A court, however, could review the software deficiency instead in terms of the manufacturing-defect theory. Here, the court need only conclude that the software failed because the program was actually built deficiently; that the execution of an admittedly reasonable software design was flawed. Such reasoning calls for a subtle distinction between the two senses of "design." That is, it envisions design of software as more akin to the manufacture of a product than to the design of a product. This distinction is supported by the fact that a "bug" in software can be corrected (much like a manufacturing defect-e.g., a

107. Id. § 2(b).

108. For a general discussion of this issue, see Restatement (ThIRD) of TorTs $\S 2 \mathrm{cmt}$. $\mathrm{f}$ (1997). 
cracked casing-can be corrected), and the software would not have been designed to include the bug, the admitted deficiency. ${ }^{109}$

There may not be a great deal of light between composition and design in the software-development context, and one may find unconvincing the distinction drawn above. But an aggressive court may not need much reason to impose strict products liability on a licensor. And, as noted in the discussion of Article 2, any perceived impotence of the implied warranty of merchantability provision may provide courts all the incentive they need.110

Once the defect issue is resolved, there are still other elements of the strict products liability theory that must be confronted to make sense of the Restatement's application to defective software. The next few Sections consider the reinaining threshold issues.

\section{B. The "Tangible" Property Requirement}

Section 19 of the Restatement limits the scope of strict products liability law to "tangible personal property" and to "[o]ther items ... when the context of their distribution and use is sufficiently analogous to the distribution and use of tangible personal property that it is appropriate to apply the rules stated in this Restatement."111 While it would be difficult to force licensed software into the "tangiblepersonal-property" category, licensing of software is sufficiently analogous to the transfer of tangible personal property to support the application of strict products liability principles.

The comments to Restatement section 19 draw a distinction, in the case of intangible property, between intangible property in the form of information (akin to the subject matter of section 2B-404), which

109. I am indebted to Professor David Frisch for this observation.

110. Cf. Escola v. Coca-Cola Bottling Co., 150 P.2d 436, 441 (Cal. 1944) (Traynor, J., concurring). Traynor wrote:

The inference of negligence inay be dispelled by an affirmative showing of proper care .... An injured person, however, is not ordinarily in a position to refute such evidence or identify the cause of the defect, for he can hardly be familiar with the manufacturing process as the manufacturer himself is. In leaving it to the jury to decide whether the inference has been dispelled, regardless of the evidence against it, the negligence rule approaches the rule of strict liability. It is needlessly circuitous to make negligence the basis of recovery and impose what is in reality liability without negligence. If public policy demands that a manufacturer of goods be responsible for their quality regardless of negligence there is no reason not to fix that responsibility openly.

Id. See also Siegler v. Kuhlman, 502 P.2d 1181, 1185 (Wasl. 1972), in which the Washington Supreme Court held,

The rule of strict liability rests not only upon the ultimate idea of rectifying a wrong and putting the burden where it slould belong as a matter of abstract justice, that is, upon the one of the two innocent parties whose acts imstigated or inade the larm possible, but it also rests on problems of proof....

Id.

111. Restatement (ThIRD) of TORTS $\$ 19$ (a) (1997). 
clearly would not be the type of intangible property contemplated by the 2B-403(b) warranty, on the one hand, and " $[t]$ he second major category of intangible, harm-causing products [that] mvolves the transmission of intangible forces such as electricity and $X$ rays," 112 on the other. The subject matter of the 2B-403(b) implied warranty is more like the intangible that "involves the transmission of intangibles forces" than it is like information. This conclusion is supported by the distinction drawn in Article 2B between sections 2B-403 (computer programs that process data) and $2 \mathrm{~B}-404$ (information). ${ }^{113}$ The proposed statute itself tracks the lines of the distimction drawn coincidentally in the Restatement. In fact, the Restatement comment further supports this line of argument by noting that, although when electricity "enters the customer's premises" it is a product, "before passing the meter" it is a service. ${ }^{114}$ Similarly when the defective software is installed in the licensee's computer system, it becomes a product.

\section{C. "Property Other Than the Defective Product Itself"}

The Restatement provides that the seller of a defective product may be liable for personal injury as well as for harm to "the plaintiff's property other than the defective product itself."115 Applied to the software licensing context in the terms posited above, that would mean that when the software fails and the millennium-bug nightmare materializes, the licensor would be liable for the licensee's loss of the value of its accounts-receivable records. The licensor would not, however, be liable on a products liability theory for the difference in the value of the software for which the licensee contracted and the software licensor tendered. And, it might also avoid liability for the damage to other software programs or other systems compromised by the defective software. But the loss of the accounts-receivable records would constitute harm to "plaintiff's property other than the defective product itself," and would be recoverable on the strict products liability theory. Further, the comment to section 21 makes clear that "characterization of a claim as harm to other property may trigger liability not only for the harm to physical property but also for incidental economic loss."116

To an extent, the contours of the limitation imposed by the "harmto-other-property" requirement have been determined by the substance of the otherwise available warranty protections heretofore provided by Article 2 of the U.C.C. The fact that the products liability law entrusts to

112. Id. $\$ 19 \mathrm{cmt} . \mathrm{d}$.

113. See U.C.C. $\S \S 2 B-403,2 B-404$ (Draft, Mar. 1998).

114. RestateMENT (THIRD) OF TORTS $\$ 19 \mathrm{cmt}$ d (1997).

115. Id. § 21(c).

116. $I d . \S 21 \mathrm{cmt} . \mathrm{e}$. 
the Article 2 warranties the protection of property interests not vindicated by the Restatement's formulation may perhaps be best understood as a creature of the Article 2 warranties' fundamental integrity. But once the warranty protections of Article 2 are unavailable to a buyer, here licensee, it might well not be appropriate to construe too broadly the "other-property" limitation.

\section{The Curious Result That Would Remain}

To emphasize the incoherence of a regime that would need to find quality protection for licensees in the strict products liability law, and to demonstrate the incongruity of reading the Article $2 \mathrm{~B}$ implied warranty of merchantability too narrowly, we must recogmize the result of applying both section $2 \mathrm{~B}-403$ and strict products liability theory to the following case: imagine software failing; as a result of that failure, the software being rendered worthless; the failure damaging the licensee's other software; and, lastly, the failure harming the licensee because the failure destroys the licensee's accounts-receivable records. If the courts were left with no choice but to provide licensees recovery under a strict products liability theory, then we would confront the curious result that the licensee could recover for the lost accounts-receivables records but not for the loss of the value of the defective software itself or for the casualty to other software or systems damaged by the defective software.

\section{E. Conclusion}

Certainly the innovation suggested here-which would require courts to infer from limitations in the non-mass-1narket software implied warranty of merchantability a recovery theory that uses tort principles to redress the failure of contract-would test the limits of the strict products liability theory. My argument is that the implied warranty of merchantability in Article $2 \mathrm{~B}$ should be construed to provide real protection to custom-designed software licensees. To the extent that there may be differences between the application of parallel commercial law formulations, those differences should be the product of substantial distinctions in the coincident subject matter.

\section{CONCLUSION}

This Article, admittedly composed by one who is, to say the least, skeptical of the Article $2 \mathrm{~B}$ project, has posited a conception of deficient products law that attempts to be true to the Llewellynesque tradition. That is, the thesis urged here is based on the conclusion that all law emerges in context, and once a liability theory has seen the light of day, the courts (at the insistence of transactors) are wont to give that theory root in any available transactional soil. 
The arguments of those who would insulate licensors from liability may well backfire, and the construction of the products liability law offered here provides one means to undermine the licensor lobby's best-laid plans. Make no mistake: courts may look to products liability theory even once the software licensing law formulates a real warranty of merchantability. But a substantial implied warranty of merchantability can minimize this look to tort and, consequently, increase certainty for all parties.

The emergence of such a warranty truly in context may take time. Because the software licensor lobby has rushed the promulgation of uniform software licensing law, formulating industry protective legislation before the subject technology and transactional patterns have matured to the point at which a "sense of the situation" and "immanent justice" can crystallize, the courts may well be deprived of the sort of substantial warranty that can mimimize resort to tort. Hence, courts may need to find and apply other theories that vindicate licensees' rights. Ultimately, then, it may quite ironically be the case that the licensors who have been so eager to insulate their business from the too aggressive use of licensee-friendly recovery theories may have to contend with the uncertainties of a strict products liability calculus. This is the case, quite simply, because their industry has not yet become sufficiently "ordinary" to make an implied warranty of merchantability theory of recovery viable. If the drafters of Proposed Article 2B are right, if they have asked the right questions and determined that the warranty of merchantability is impotent in this setting, then, in fact, they have presented what may be the best argument for the application of products liability theory: the implied warranty of merchantability, even conscientiously drawn, is currently impotent in this setting. And this, I posit, counsels delaying codification until we have reached the Llewellynesque moment. 